\title{
Effects of soil acid stress on the survival, growth, reproduction, antioxidant enzyme activities, and protein contents in earthworm (Eisenia fetida)
}

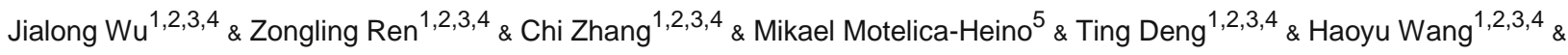

Jun Dai $1,2,3,4$

\section{Abstract}

This study focused on the study of earthworm survival, growth, reproduction, enzyme activities, and protein contents to evaluate and predict the effects of different soil $\mathrm{pH}$ levels and determine the optimal risk assessment indicators for the effects. Survival rate, growth rate, and cocoon number as well as four enzyme (glutathione peroxidase (GSH-PX), superoxide dismutase (SOD), peroxidase (POD), and catalase (CAT)) activities and two proteins (total protein (TP) and metallothionein (MT)) contents in earthworms were determined to characterize the responses of earthworm activity to five soil $\mathrm{pH}$ levels. These biological datasets (survival, growth, and reproduction) were compared with biochemical indexes (GSH-PX, SOD, POD, CAT, TP, and MT), mainly using biphasic dose-response models. The results indicated that the soil $\mathrm{pH}$ value had significant inhibitory effects on the survival, growth, and reproduction of earthworms beginning with 3.0, 4.0, and 5.2, respectively. The dose-response models (J-shaped and inverted U-shaped curves) statistics indicated that the critical values (ECZEP) of the GSH-PX, SOD, POD, CAT, TP, and MT inhibited by soil acid stress were 3.46, 3.76, 3.35, 3.54, 3.50, and 3.96 (average 3.60), respectively. In the present study, the fitting curve analysis showed that the responses of the CAT activities and TP and MT contents in earthworm in response to soil $\mathrm{pH}$ have the behavior of hormesis.

Keywords Soil acidity ${ }^{\circ}$ Growth ${ }^{\circ}$ Reproduction ${ }^{`}$ Biochemical response ${ }^{\circ}$ Hormetic effect ${ }^{\circ}$ Eisenia fetida

\section{Responsible editor: Philippe Garrigues}

* Zongling Ren

zren@scau.edu.cn

* Jun Dai

jundai@scau.edu.cn

1 College of Natural Resources and Environment, South China Agricultural University, 483 Wushan Road, Tianhe District, Guangzhou 510642, China

2 Key Laboratory of Arable Land Conservation in South China, Ministry of Agriculture People's Republic of China, Guangzhou 510642, China

3 Key Laboratory of the Ministry of Land and Resources for Construction Land Transformation, Guangzhou 510640, China

4 Guangdong Province Key Laboratory of Land Use and Consolidation, Guangzhou 510140, China

5 Université d'Orléans, CNRS/INSU Institut des Sciences de la Terre d'Orléans, UMR 6113, Campus Géosciences, 1A rue de la Férollerie, 41071 Orléans, France

\section{Introduction}

Soil acidification has naturally occurred across much of tropical and subtropical regions of China where underlying geology has poor buffering capacity and rainfall levels are high enough to leach base cations from the bulk soil (Hodson and Donner 2013). Moreover, soil pH has been furthered lowered by agricultural practices such as the use of nitrogenous fertilizers (Zeng et al. 2017; Tian and Niu 2015) and anthropogenic atmospheric acid deposition (Qiao et al. 2015; Zhao et al. 2009). Guo et al. (2010) reported that soil pH in the major croplands of China had exhibited a widespread decline of 0.13-0.80 units among various soil types during the 1980s2000s, mainly due to the increasing $\mathrm{N}$ fertilizer applications. The intensified acidification, which altered biogeochemistry of soil ecosystem and adversely affected biota (Wei et al. 2017; Kunito et al. 2016; Zhang et al. 2015c), has become a major cause of crop yield reduction (Brown et al. 2008) and serious environmental problems, i.e., aluminum toxicity and 
heavy metal activation (Guo et al. 2010; Kunito et al. 2016; Zhao et al. 2015).

Given that earthworms represent a significant proportion of the soil fauna biomass (Edwards 2004) and are naturally in contact with the soil phases, they are considered as the prior organisms in terrestrial ecotoxicology (Shi et al. 2017; Liu et al. 2011). Soil $\mathrm{pH}$ is a major factor limiting the abundance and distribution of earthworms in soils, and different earth-worm species show different sensitivity and tolerance to soil $\mathrm{pH}$ (Chan and Mead 2003). According to previous field work, neutral $\mathrm{pH}$ has been suggested as optimal for many species, while soil $\mathrm{pH}<4.3$ is not favorable to most of earthworm species (McCallum et al. 2016; Moore et al. 2013; Edwards and Bohlen 1996). However, the available information in the literature on the physiological and biochemical responses at different $\mathrm{pH}$ level and $\mathrm{pH}$ threshold of earthworm in natural soil is still limited.

Since earthworms are sensitive to soil $\mathrm{pH}$, their survival, density, diversity, and activity are often used as bioindicators to evaluate the risk of soil acidification (Homan et al. 2016; McCallum et al. 2016; Chan and Mead 2003). Most of the previous studies have revealed that earthworm density, diversity, and survival are typically low in acidic soils (Moore et al. 2013; Chan and Mead 2003; Rusek and Marshall 2000), and few studies have attempted to explore the biochemical response of earthworm to soil acidification (Zhang et al. 2015a). However, their survival is dependent on efficient radicalscavenger system in earthworms, which includes spe-cial proteins and enzymatic antioxidants, such as catalase (CAT), peroxidase (POD), superoxide dismutase (SOD), and glutathione peroxidase (GSH-PX). They can scavenge radicals induced by exogenous stress (e.g., heavy metals, aluminum, and organic pollutants) to protect organisms from damage (Liu et al. 2018; Dedeke et al. 2016; Li et al. 2014; Zhang et al. 2009; Mosleh et al. 2003). Moreover these biochemical responses may be more sensitive to chemical stress before sublethal effects, such as inhibition of growth and reproduction abovementioned, become apparent (Velki and Hackenberger 2013). Therefore these biochemical responses in earthworm to soil acidity should be investigated as well to provide sensitive and prognostic indicators for the assessment of soil quality.

Moreover the physiological and biochemical responses in living organisms to environmental stress are a reparative process in nature that is adaptive to maintain an adequate survival capacity. They are typically represented in graphs as a biphasic dose-response that either a J-shaped or an inverted Ushaped curve, depending on the endpoint measured (Calabrese and Blain 2005; Calabrese and Baldwin 2003). The hormetic dose-response relationship has been observed in many organisms that from animals and plants to microbiota and characterized by low-dose stimulation and high-dose inhibition (Jia et al. 2015; Calabrese and Baldwin 2003). Until now, very few studies have reported the occurrence of the hormetic effect of environmental toxic agents (e.g., cadmium and temephos) on physiological and biochemical parameters in earthworms (Zhang et al. 2009; Hackenberger et al. 2008). Additionally, most of previous toxicological studies have focused only on the adverse effects of environmental toxic agents at high concentrations, but ignored low-dose effect (Calabrese and Baldwin 2003).

In this study, Eisenia fetida earthworms were used as mod-el species (OECD 2004; Nahmani et al. 2007; Shi et al. 2017) and exposed to five-field relevant $\mathrm{pH}$ levels in latosolic red soil artificially acidified by adding dilute sulfuric acid for $7,14,21$, and 28 days, respectively. The endpoints were assessed at each time interval including earthworm mortality, growth, and the reproduction, while at the end of incubation, the ac-tivities of antioxidant enzymes (CAT, POD, SOD, and GSH-PX) and protein contents (total protein and metallothionein) were determined as well. The objectives of this study were to

(1) assess the effect of soil acidity on the survival, reproduction, and biochemical response of earthworm in natural soil to ascertain the soil $\mathrm{pH}$ threshold for Eisenia fetida and (2) examine if the hormetic effects of soil acidity on earthworms occur at molecular level, especially at the low dose of acid (i.e., high $\mathrm{pH}$ ), so as to allow more accurate assessments of the real field effects of acid stress onto earthworms.

\section{Materials and methods}

\section{Soil and biological material preparation}

Surface soil was collected from a botanical garden $\left(23^{\circ} 9^{\prime}\right.$ 33" N, $113^{\circ} 21^{\prime} 22^{\prime \prime}$ E) of the South China Agricultural University, Guangdong Province, China. The upper 10-cm soil was used in this study after having been air-dried and then sieved at $3 \mathrm{~mm}$. The soil has a $\mathrm{pH} 4.13$ with a high organic matter content of $42.63 \mathrm{~g} \mathrm{~kg}^{-1}$, a clay content of $22.98 \%$, and total $\mathrm{N}$ content of $1.85 \mathrm{~g} \mathrm{~kg}^{-1}$. To ensure the growth and reproduc-tion of earthworms during the experiment, cattle dung was added into soil as a food source. The dung was air-dried and sieved at $3 \mathrm{~mm}$ before use. The total organic $\mathrm{C}$, and $\mathrm{N}, \mathrm{C}$-to- $\mathrm{N}$ ratio, and $\mathrm{pH}$ value were 170.68 and $9.43 \mathrm{~g} \mathrm{~kg}^{-1}, 18.10$ and 8.03 , respectively.

The earthworms, Eisenia fetida, were purchased from a commercial source (Guangzhou, Guangdong, China). Before experiment, they were acclimatized for 7 days at 25 ${ }^{\circ} \mathrm{C}$ in the dark with cattle dung in large feed boxes. Then, they were removed form culture, rinsed with distilled water, and placed on the damp filter in Petri dishes for $48 \mathrm{~h}$ in the dark at $25{ }^{\circ} \mathrm{C}$ to void gut contents. The earthworms we used in the experi-ment were adult with well-developed clitellum (average fresh weight $0.36 \pm 0.03 \mathrm{~g}$ ). 


\section{Experimental design}

Factorial design $5 \times 4$ was used with five soil $\mathrm{pH}$ of $6.3,5.2$, $4.0,3.4$, and 3.0, based on the current $\mathrm{pH}$ condition in southern China. The second experimental factor was exposure duration of 7, 14, 21, and 28 days. Finally, 60 microcosms with 3 replicates per treatment were established. Microcosms were plastic containers $(9 \mathrm{~cm} \times 12 \mathrm{~cm} \times 13 \mathrm{~cm})$ filled with $450 \mathrm{~g}$ of soil and $50 \mathrm{~g}$ of dry cattle dung. The mixtures were then preincubated at $25{ }^{\circ} \mathrm{C}$ for 7 days at $30-40 \%$ of their waterholding capacity prior to the experiment (Tejada et al. 2010). After the pre-incubation period, different amounts $(0,30,45$, 60 , and $75 \mathrm{mmol} \mathrm{kg}^{-1}$ ) of dilute sulfuric acid was added into soil to give five final soil $\mathrm{pH}(6.3,5.2,40,3.4$, and 3.0, respectively). The unamended soil was used as a control $(\mathrm{pH}$ 6.3).

About 8.0 -g fresh weights (approximately 20 individuals) of adult earthworms were introduced into each microcosm which was covered with a fine nylon mesh to keep the earthworms from escaping. All microcosms were kept in a growth chamber at $23 \pm 2{ }^{\circ} \mathrm{C}$. Continuous light (400-800 lx) was provided to prevent escape (Zhou et al. 2016; Chen et al. 2017). Soil moisture contents were adjusted by weight every 2 days. The soil $\mathrm{pH}$ was monitored at the end of experiment as well, and the $\mathrm{pH}$ shift was not significant ( \pm 0.08 units).

\section{Determination of survival and reproduction of earthworms}

Surviving worms and cocoons in the microcosms were collected by hand sorting, washed in distilled water, dried on paper towels, and weighed at days of 7, 14, 21, and 28, respectively. Earthworms were considered to be dead if they did not respond to gentle mechanical stimulation of the anterior region, and they were considered to have died if they were missing (Wu et al. 2011). The survival rate (\%) was the percentage of worms surviving at time $T$ relative to the initial worms. The growth rate of the earthworms was calculated by:

${\text { Growth rate } g=\text { day }^{-1} \frac{W-W_{0}}{T}}_{1 / 4}^{T} \quad \partial_{p}$

where $\mathrm{W}$ is the fresh weight $(\mathrm{g})$ of earthworms at $\mathrm{T}$ days, $\mathrm{W}_{0}$ is the fresh weight $(\mathrm{g})$ of earthworms before the incubation, $T$ is the exposure duration period $(7,14,21$, and 28 days).

\section{Biochemical assay of earthworms}

For 28 days of exposure and for each microcosm, three earthworms, which were selected randomly, were washed, gut purged, put into a mortar, and grinded. The homogenizer buffer fluid (Tris $50 \mathrm{mmol} \mathrm{L}^{-1}$, DTT $1 \mathrm{mmol} \mathrm{L}^{-1}$, EDTA
$1 \mathrm{mmol} \mathrm{L}^{-1}$, sucrose $\left.250 \mathrm{mmol} \mathrm{L}^{-1}, \mathrm{pH} 7.6\right)(\mathrm{w} / \mathrm{v}=1: 9)$ was then added (Wu et al. 2011; Zhang et al. 2009). The homogenate was centrifuged at $3000 \mathrm{~g}$ for $10 \mathrm{~min}$ at $4{ }^{\circ} \mathrm{C}$ and the supernatants were stored for the assay for activities of antioxidant enzymes (CAT, POD, SOD, and GSH-PX) and the contents of total protein (TP) and metallothionein (MT). All procedures were carried out at $4{ }^{\circ} \mathrm{C}$. The determinations of enzyme (CAT, POD, SOD, and GSH-PX) activities were performed according to the method described by Zhou et al. (2016): CAT activity was measured at $405 \mathrm{~nm}$ by an assay of hydrogen peroxide based on the formation of its stable complex with ammonium molybdate. One unit of CAT activity was defined as the decomposition of $1 \mathrm{mmol}$ of hydrogen peroxide per second. POD activity was measured with guaiacol at $470 \mathrm{~nm}$. In the presence of $\mathrm{H}_{2} \mathrm{O}_{2}$, POD catalyzed the transformation of guaiacol to tetra-guaiacol and the reaction mixture $(3 \mathrm{~mL})$ consisted of $50 \mathrm{mM}$ potassium phosphate buffer (pH 6.1), $1 \%$ guaiacol, $0.4 \% \mathrm{H}_{2} \mathrm{O}_{2}$, and $10 \mathrm{~mL}$ enzyme extract. SOD activity was determined by the method of hydroxylammonium autoxidation. One unit (U) of SOD was defined as the amount of enzyme that caused 50\% inhibition of reaction, and the result was expressed as units per milligram of protein. The GSH-PX activity was estimated by the DTNB [2-thio-2, 4-dinitrobenzoic acid] reduction method at the ab-sorbance of $412 \mathrm{~nm}$, and the result was expressed as units per milligram of protein. The TP contents were measured by the Coomassie Brilliant Blue colorimetric method at $595 \mathrm{~nm}$ ac-cording to Bradford (1976), and MT contents were determined by the enzyme-linked immunosorbent assay kit (double-anti-body sandwich enzyme-linked immunosorbent assay, ELISA). The above assay reagent kits for detection of antiox-idant enzyme activities, and contents of TP and MT, were purchased from Nanjing Jiancheng Biological Engineering Institute (Nanjing, China). For the six biochemical bio-markers, the percentages of stimulation were calculated as follows (Zhang et al. 2009):

Eð\%Р $1 / 4 \quad \frac{V_{n}-V_{0}}{V_{0}} \quad 100 \%$ ð2P

where $E$ represents stimulation rate, the $V_{n}$ is the average protein contents or antioxidant enzyme activities exposed to the certain soil $\mathrm{pH}$ level on the 28th day of incubation, and $\mathrm{V}_{0}$ is the average protein contents or antioxidant enzyme activities in control (pH 6.3) on the 28th day of incubation.

\section{Statistical analysis}

All data were statistically analyzed using SAS version 9.0 (SAS Inc.) and expressed as mean \pm standard deviation (SD, $\mathrm{n}$ $=3$ ). Due to the non-normal distribution of all the parameters, a non-parametric Kruskal-Wallis test was used to determine whether there were significant differences $(p<0.05)$ in 
earthworm survival rates, growth rates, and cocoon amounts between the treatments with different soil $\mathrm{pH}$ at the certain exposure time. Principal component analysis (PCA) was performed for testing of multivariate differences between treatments using the R software version i386 3.0.2 (ade4 library) (R Development Core Team 2007). Moreover, a biphasic model (Eq. 3) for describing the dose-response relationships between soil acidity and the antioxidant enzyme activities and protein contents in earthworms after 28 days of exposure was developed to detect hormetic effects (Zhang et al. 2009):

\section{E ðx $P 1 / 4 a x^{2} p b x p c$}

ðз

where $E$ represents stimulation rate of protein contents or antioxidant enzyme activities and $\mathrm{x}$ is the soil $\mathrm{pH}$. The regression of biphasic model was performed using non-linear least squares fit with Origin 2017 (OriginLab Inc., Hampton, MA, USA), and the coefficient of determination $\left(R^{2}\right)$ was used to assess the goodness-of-fit of the model. To estimate the extent of hormesis, the ratio of AUCH/AUCZEP was used, which can be described by Eq. (4) as follows:

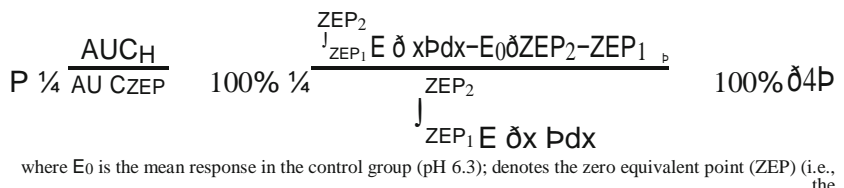

${ }^{Z E P_{i}(i=1,2)} \quad \mathrm{pH}$ when the percentage of stimulation is zero); $\mathrm{AUCH}_{\mathrm{H}}$ is the area under the hormetic zone; and the AUCZEP is the area under the non-linear curve from $\mathrm{ZEP}_{1}$ to $\mathrm{ZEP}_{2}$ (Zhang et al. 2009).

\section{Results}

\section{Effects of soil pH on earthworm survival, growth rate, and reproduction}

The survival of Eisenia fetida was not significantly affected during the 28 days of exposure by soil $\mathrm{pH} 6.3,5.2,4.0$, and 3.4. However for $\mathrm{pH} 3.0$, about $40 \%$ of earthworms were dead after 7 days of incubation (Fig. 1a). On the other hand, the changes in earthworm growth rate appeared to be both acid dose- and exposure time-dependent (Fig. 1b). The growth rate of earthworms exposed to higher soil $\mathrm{pH}(\mathrm{pH} 6.3$ and 5.2) were positive, with the biomass increasing by $0.2 \mathrm{~g}$ day in the first 14 days of exposure and then gradually decreasing to the initial level until the end of incubation. During the 28 days of exposure, the growth of earthworms exposed to soil $\mathrm{pH} 5.2$ was not obviously affected except in the first 7 days compared to that of the control $(\mathrm{pH} \mathrm{6.3)}$. The growth of earth-worms exposed to lower soil $\mathrm{pH}(\leq 4.0)$ was significantly inhibited during the experimental incubation and appeared to be acid dose-dependent $(p<0.05)$. The earthworm biomass in low $\mathrm{pH}$ soil $(\leq 4.0)$ also reduced initially and then gradually kept steady after 14 days of exposure. Compared to the control ( $\mathrm{pH} 6.3$ ), cocoon production was reduced for all acid treat-ments especially after 14 days of exposure (Fig. 1c), especially for soil pH 3.4 and 3.0, in which cocoons were not collected at all after the 7 days of exposure. Moreover, cocoon production in soils with $\mathrm{pH}$ $6.3,5.2$, and 4.0 appeared to be time-depen-dent, with longer exposure duration resulting in greater increase.

\section{Effects of soil pH on protein contents in E. fetida}

As shown in Fig. 2, after 28 days of exposure, the higher soil $\mathrm{pH}$ (5.2 and 4.0, respectively) had stimulatory effect on total protein (TP) and metallothionein (MT) contents in E. fetida, while the lower soil $\mathrm{pH}$ (3.4 and 3.0, respectively) had inhibitory effects, while the control ( $\mathrm{pH}$ 6.3) had no effect. Compared to control, the highest stimulatory effects on TP and MT contents was measured at soil pH $5.2(\mathrm{E}=18.78 \%$ and $9.78 \%$, respectively) and the lowest stimulatory effects were measured at soil $\mathrm{pH} 3.0(\mathrm{E}=-18.85 \%$ and $-13.77 \%$, respectively). Soil acidity showed inverted U-shaped dose-response curves (DRCs) for its effects on both TP and MT contents in E. fetida (Fig. 2). The biphasic model could fit the hormetic data well with $\mathrm{R}^{2}$ of 0.9967 and 0.9663 for TP and MT contents, respectively. For TP contents, $\mathrm{ZEP}_{1}$ and $\mathrm{ZEP}_{2}$ were $\mathrm{pH} 6.30$ and $\mathrm{pH} 3.53$, respectively, which meant that the stimulatory width is 2.77 . Using the direct integral method, the hormetic area $\mathrm{AUCH}_{\mathrm{H}}$ was calculated as 233.14 and the AUCZEP as 874.11. The ratio of $A_{U C H}$ to AUCZEP was $26.67 \%$. The maximal stimulatory effect $\left(E_{\max }\right)$ was $19.95 \%$ at $\mathrm{pH} 4.91$ (Fig. 2a). Similarly, for MT contents, ZEP1 and $\mathrm{ZEP}_{2}$ were calculated as $\mathrm{pH} 6.31$ and $\mathrm{pH} 3.88$, respectively, and the stimulatory width as 2.44. The hormetic area $\mathrm{AUCH}_{\mathrm{H}}$ was calculated as 218.25 and the AUCZEP as 581.54. The ratio of $\mathrm{AUCH}_{\mathrm{H}}$ to $\mathrm{AUCZEP}$ was $37.53 \%$. The maximal stimulatory effect $\left(E_{\max }\right)$ was $9.04 \%$ for pH 5.10 (Fig. 2b).

\section{Effects of soil pH on enzyme activities in $\mathrm{E}$. fetida}

The effect of soil acidity on enzyme activities in earthworms is displayed in Fig. 3. After 28 days of exposure, considering the control ( $\mathrm{pH}$ 6.3) had no effect, the GSH-PX, SOD, and POD activities in $\mathrm{E}$. fetida showed a U-shaped curve, which gener-ally declined with decreasing soil $\mathrm{pH}$ from 5.2 to 4.0 and then increased at lower soil $\mathrm{pH}(<4.0)$, indicating the hormetic phenomenon did not occur for the three enzymes at the end of incubation. Compared with the control $(\mathrm{pH}$ 6.3), the lowest stimulatory effects $\left(\mathrm{E}_{\min }\right)$ were measured at $\mathrm{pH} 5.2$ for GSH-PX $(-28.92 \%)$, pH 4.0 for SOD (-25.60\%), and $\mathrm{pH} 5.2$ for POD ($31.14 \%$ ), while at soil $\mathrm{pH} 3.0$, the GSH-PX, SOD, 

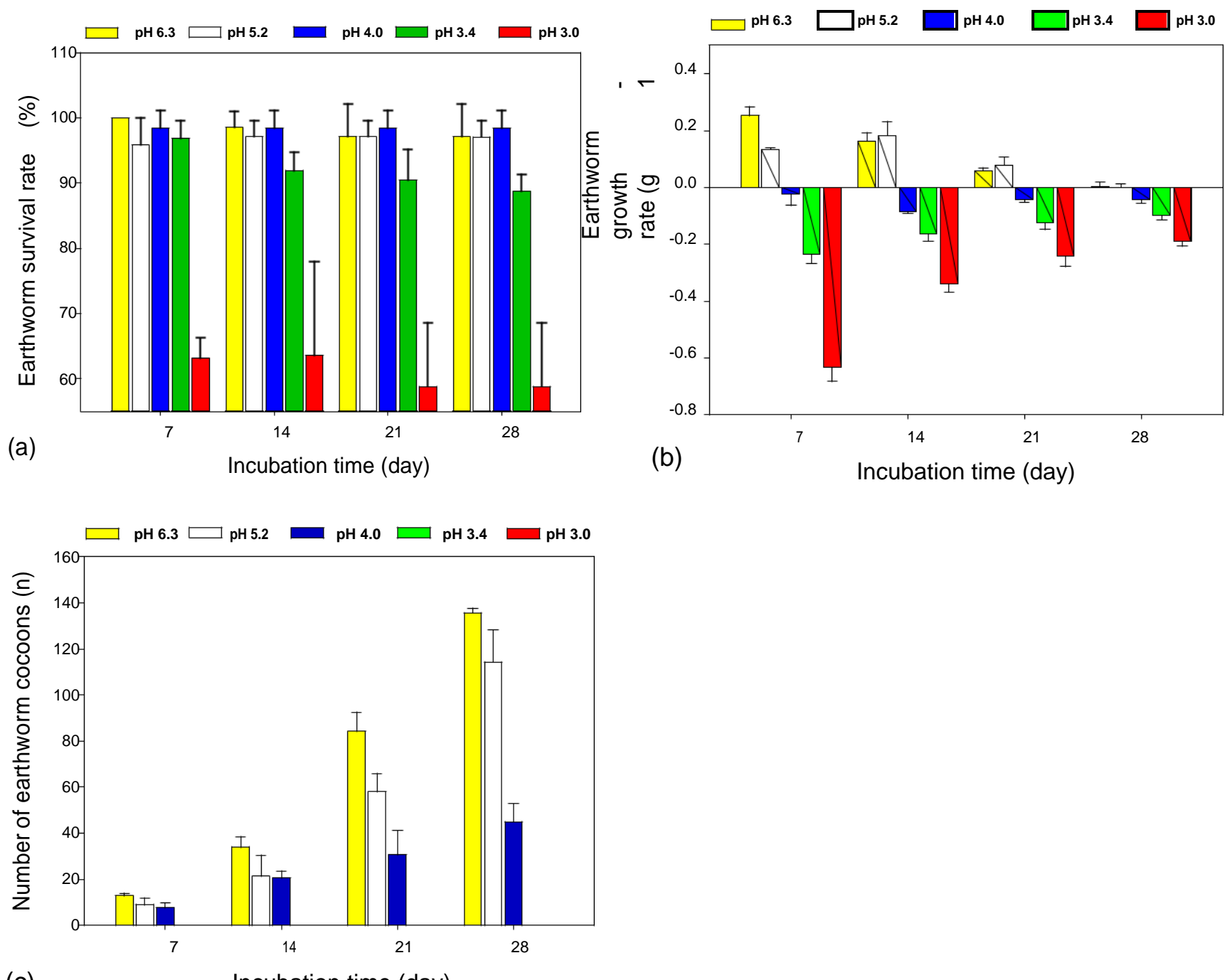

(c)

Incubation time (day)

Fig. 1 Survival rate (a), growth rate (b), and cocoon production (c) of Eisenia fetida exposed to different soil pH levels (mean \pm standard deviation, $\mathrm{n}=3$ )

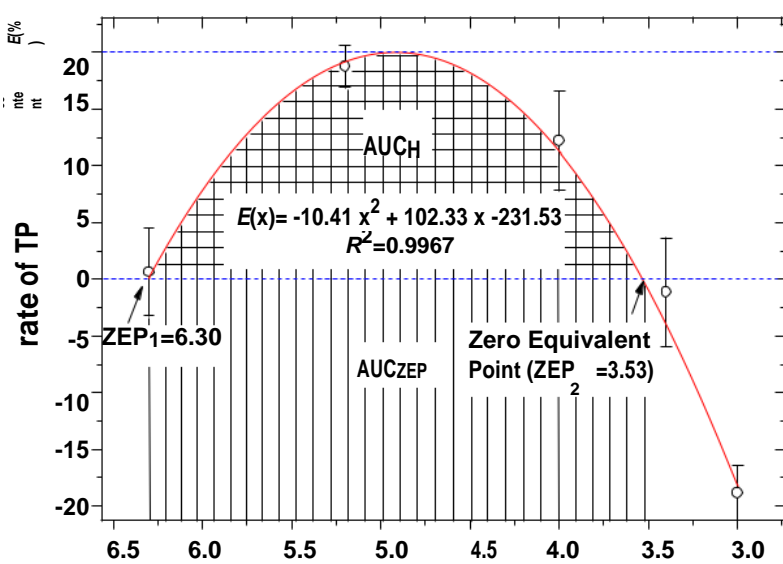

(a)

Soil pH

Fig. 2 Total protein (TP) and metallothionein (MT) contents in Eisenia fetida after 28 days of exposure to five soil $\mathrm{pH}$ levels $(\mathrm{n}=3)$. $\mathrm{E}_{0}$ is the zero effect; $E_{\max }$ is the maximal stimulatory effect; $\mathrm{ZEPi}(i=1,2)$ is the zero equivalent point; $\mathrm{AUC}_{\mathrm{H}}$ is the area under the hormetic zone, and the

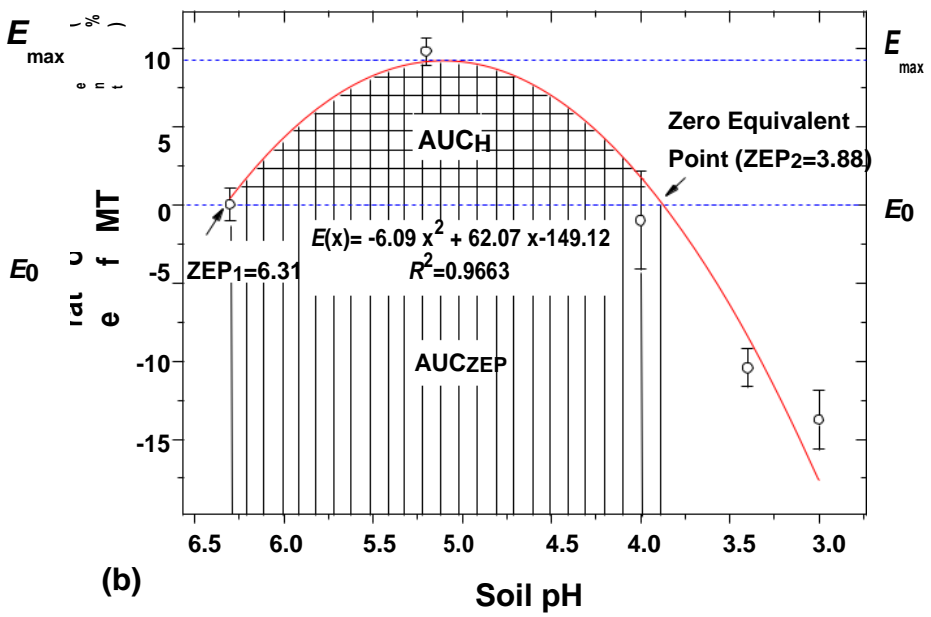

AUCZEP is the area under the non-linear curve from ZEP1 to ZEP2. White circle indicates experimental data; fullwidth hyphen indicates biphasic model fit 


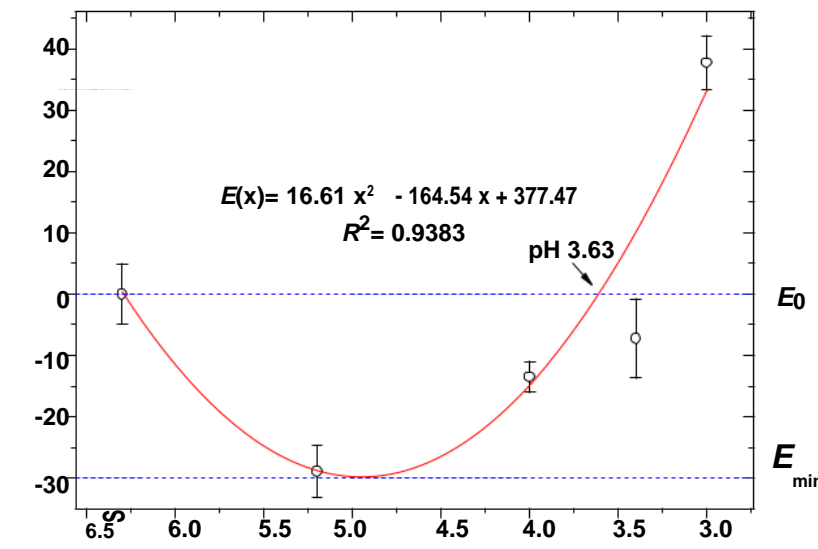

(a)

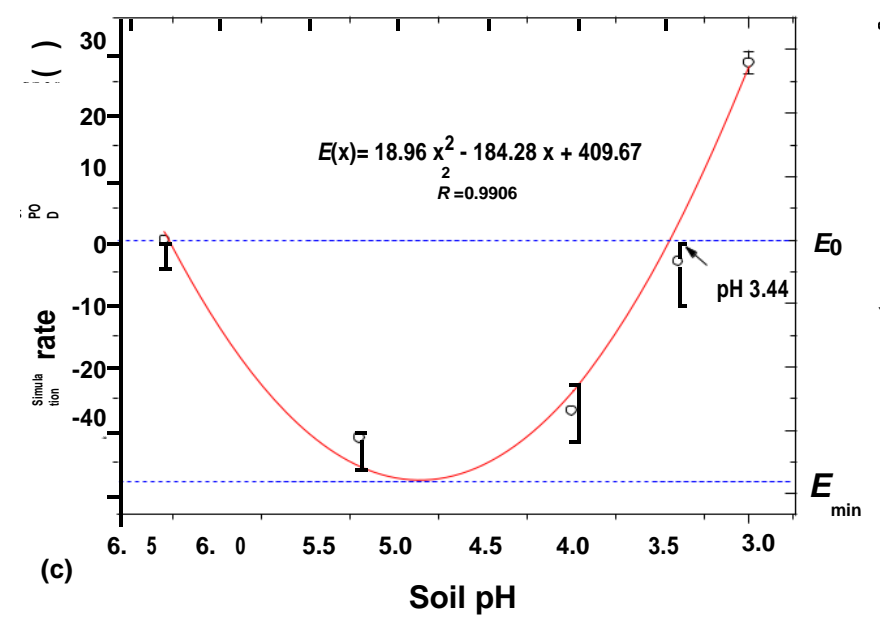

Fig. 3 The GSH-PX, SOD, POD, and CAT activities in Eisenia fetida after 28 days of exposure to five soil $\mathrm{pH}$ levels $(n=3)$. $E_{0}$ is the zero effect; $E_{\max }$ and $E_{\min }$ are maximal stimulatory effect and minimum stimulatory effect, respectively; $\mathrm{ZEP}_{i}(i=1,2)$ is the zero equivalent

and POD activities were stimulated by $37.71 \%, 46.32 \%$, and $27.99 \%$, respectively. The biphasic models could fit the data well with $\mathrm{R}^{2}$ of $0.9383,0.9728$, and 0.9906 for the GSH-PX, SOD, and POD activities, respectively (Fig. 3a-c). The zero effects equal to that of the control were calculated as soil $\mathrm{pH} 3.63,3.56$, and 3.44 for the GSH-PX, SOD, and POD activities in E. fetida, respectively. Unlike the GSH-PX, SOD, and POD, CAT activities in E. fetida exhibited typical hormetic response to soil acidity after 28 days of exposure, i.e., the higher soil $\mathrm{pH}$ (5.2 and 4.0) had stimulatory effect on CAT activities in $\mathrm{E}$. fetida $(\mathrm{E}=$ $36.67 \%$ and $19.56 \%$, respec-tively), while the lower soil $\mathrm{pH}(3.4$ and 3.0) had inhibitory effects $(E=-3.62 \%$ and $-42.96 \%$, respectively), considering the control $(\mathrm{pH} 6.3)$ had zero effect (Fig. 3d). The inverted U-shaped DRC between soil $\mathrm{pH}$ and CAT activities in E. fetida could be fitted with a biphasic model with $\mathrm{R}^{2}$ of $0.9963 . \mathrm{ZEP}_{1}$ and $\mathrm{ZEP}_{2}$ were calculated as $\mathrm{pH} 6.30$ and $\mathrm{pH}$ 3.60 , respective-ly, and the stimulatory width was 2.70 . Using the direct inte-gral method, the hormetic area $\mathrm{AUCH}_{\mathrm{H}}$ was calculated to be
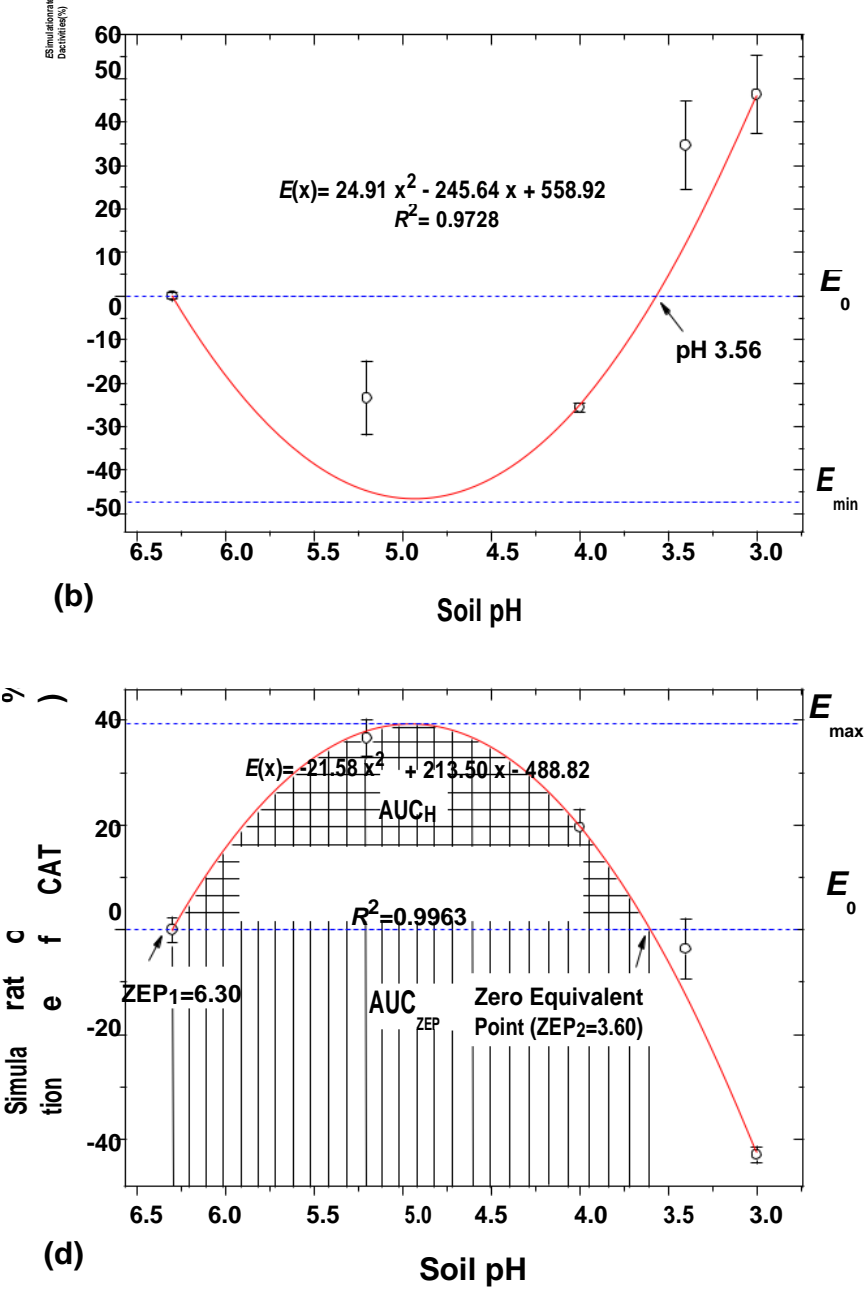

point; $\mathrm{AUC}_{\mathrm{H}}$ is the area under the hormetic zone, and the $\mathrm{AUC}_{\mathrm{ZEP}}$ is the area under the non-linear curve from $\mathrm{ZEP}_{1}$ to $\mathrm{ZEP}_{2}$. White circle indicates experimental data; fullwidth hyphen indicates biphasic model fit

229.57 and the AUCZEP to be 1547.90, and the ratio of AUCH to AUCZEP was $14.83 \%$. The maximal stimulatory effect ( $\left.E_{\max }\right)$ was $39.24 \%$ at $\mathrm{pH} 4.95$.

\section{General effects of soil pH on earthworm growth, reproduction, and biochemical characteristics}

Principal component analysis (PCA) was performed to ana-lyze the interrelationships between growth and reproduction index and biochemical variables in earthworms and to identify general trends of soil $\mathrm{pH}$ effects on earthworm activity lived in soils after 28 days (Fig. 4). In PCA correlation circle (Fig. 4a), 90.7\% of information was explained by the first two principal components (F1 and F2), in which F1 accounted for $81.3 \%$ of total explained variance. This indicated that F1 could repre-sent the majority of total data variability. Moreover, the growth index was positively correlated with cocoon produc-tion, the protein contents (TP and MT) and the CAT activities ( $p<0.05)$, but negatively correlated with the activities of the 


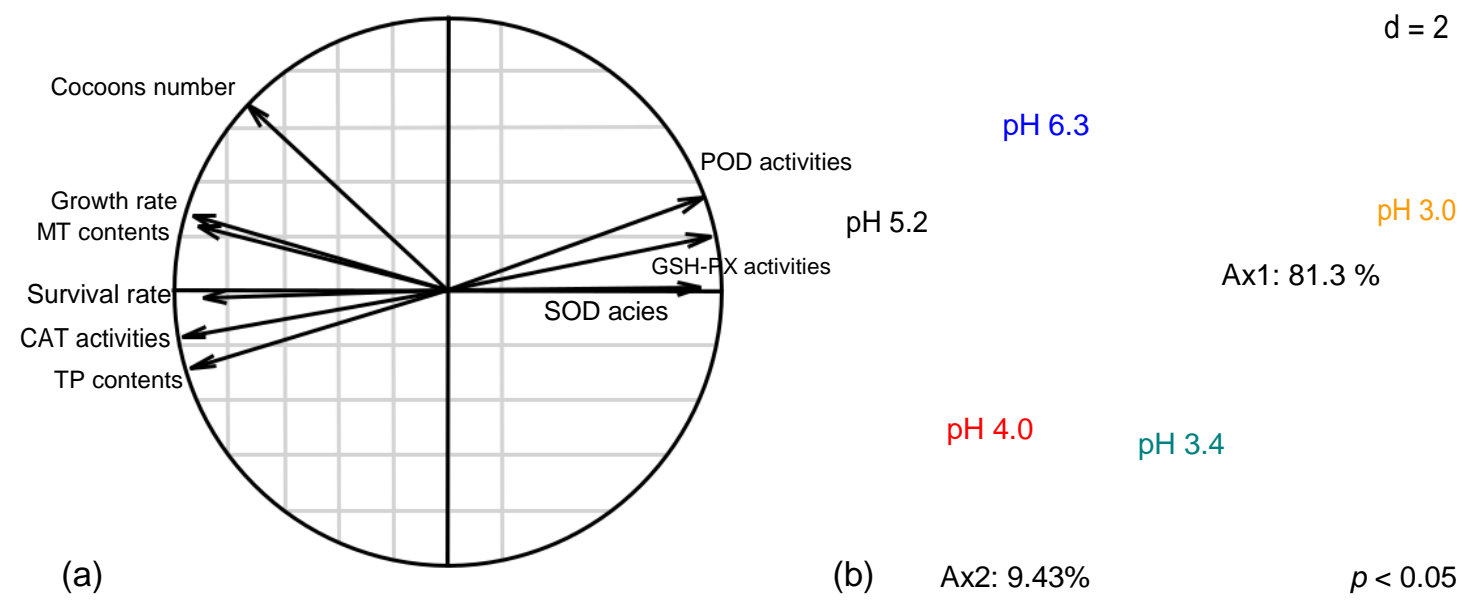

Fig. 4 Principal component analysis of growth and reproduction index and biochemical characteristics of earthworms exposed for 28 day in factorial $F 1$ and F2 planes $(n=3, p<0.05)$. a Correlation circles of

POD, SOD, and GSH-PX ( $p<0.05)$. Cocoon production has no significant correlation with TP contents and POD activities. Score plot of PCA was used to explore variation and trend of earthworm growth and reproduction index and biochemical variables under the different soil acid stress (Fig. 4b). The result showed that F1 opposed the treatments with higher soil $\mathrm{pH}(\geq 4.0)$ to the treatments with lower soil $\mathrm{pH}$ (3.4 and 3.0). Earthworms living in the soil with lower $\mathrm{pH}$ (3.4 and 3.0) had higher POD, SOD, GSH-PX activities, but lower CAT activ-ities and TP and MT contents than those living in soil with higher soil $\mathrm{pH}(\geq 4.0)$ (Fig. 4b, $\mathrm{p}<0.05$ ). Earthworms in con-trol soil $(\mathrm{pH}$ 6.3) were significantly separated from those in acid treatments on the F2 axis $(9.4 \%$ of total variance) (Fig. $4 b, p<0.05$ ), indicating that all the acid treatments had lower cocoon production than the control.

\section{Discussion}

Soil acidification has been accelerated greatly in tropical and subtropical regions of China in recent decades due to various anthropogenic activities, such as increasing $\mathrm{N}$ fertilizer applications and anthropogenic atmospheric acid depositions. In Guangdong Province, the average soil $\mathrm{pH}$ has been decreased from 5.70 to 5.44 in the last 30 years; moreover, for $25.8 \%$ of lateritic soil and $26.6 \%$ of red soil, $\mathrm{pH}$ values had been significantly declined (Guo et al. 2010). The acidified soil may constrain the earthworm survival, growth, and reproduction. Our results identified the lower soil $\mathrm{pH}$ threshold of 3.0 for the presence of $\mathrm{E}$. fetida. This $\mathrm{pH}$ threshold was lower than the values reported for Lumbricus terrestris ( $\mathrm{pH} 3.6-5.0)$ by Homan et al. (2016) and for Allolobophora chlorotica $(\mathrm{pH}$ 4.7-5.7) by McCallum et al. (2016), indicating that E. fetida has a wider tolerance range of soil $\mathrm{pH}$ and survival earthworm survival, growth, reproduction, enzyme activities, and protein contents in treatments. b Projection of experimental points according to treatments with different soil $\mathrm{pH}$

is not an ecological sensitive parameter for assessing soil acid-ification. The low survivorship in very acid soils may be at-tributed, in part, to disruptions in physiological processes in earthworms, such as electrolyte and mucus production (Rusek and Marshall 2000) caused by the exposure to the high concentration of $\mathrm{H}$ ions and inorganic $\mathrm{Al}$ which is mobilized in acidified soils (Edwards and Bohlen 1996; Zhang et al. 2013; Homan et al. 2016).

In comparison, significantly lower growth rates were found in the treatment of soil $\mathrm{pH} \leq 4.0$ during the whole incubation time, showing that growth rate was relatively more sensitive than survival. Moreover, cocoon production was particularly sensitive to soil acidification, with a decrease in the treatment of soil $\mathrm{pH} \leq 5.2$ during the whole period of incubation especially after 14 days of exposure $(p<0.05)$. Briefly, the sensitivity of the endpoints for assessing the effect of soil acid stress at the tested levels on E. fetida was in the order of cocoon production $(\mathrm{pH} \leq 5.2)>$ earthworm growth $(\mathrm{pH} \leq 4.0)$ $>$ earth-worm survival $(\mathrm{pH} \leq 3.0)$. Our results were consistent with those found in artificial soils contaminated by zinc (Spurgeon and Hopkin 1996), field-contaminated, metalpolluted soils (Nahmani et al. 2007) and soils contaminated by herbicides (Mosleh et al. 2003). The differences in earthworm life cycle parameters at different soil $\mathrm{pH}$ may result from the disruption of the distribution of energy budget for metabolic costs, including for the system development and growth and for maintenance and repair (Spurgeon and Hopkin 1996). However, the strategy that E. fetida adopted when exposed to acidic soil is still unclear.

While little is known about of the biochemical and molecular responses of E. fetida to soil acidity, they are expected to be more informative and may link to the inhibition of growth and reproduction, thus providing a more comprehensive understanding of the effects of soil 
acid stress on earthworms (Wu et al. 2011; Zhang et al. 2015a). The antioxidant enzymes would have certain synergetic effects on cleaning out reactive oxygen species (ROS) caused by normal metabolism or environment stress (Hu et al. 2016; Zhou et al. 2016). They protect cells against the adverse effects of ROS. During elimina-tion of ROS, the antioxidant enzymes, POD and SOD are

a first-line defense against environmental stress, can remove ROS from organisms via the reaction $2 \mathrm{O}_{2}{ }^{-}+2 \mathrm{H}^{+} \rightarrow$ $\mathrm{H}_{2} \mathrm{O}_{2}+\mathrm{O}_{2}$ (Zhang et al. 2015a, b, 2014; Liu et al. 2018; Wang et al. 2016), which in turn is detoxified by CAT into $\mathrm{H}_{2} \mathrm{O}$ and $\mathrm{O}_{2}$ (Sanchez-Hernandez et al. 2014; Zhang et al. 2015b). The GSH-PX also reduces $\mathrm{H}_{2} \mathrm{O}_{2}$ and plays an important role in the removal of ROS (Li et al. 2014). In this work, the overcompensation theory is the possible mechanism of action for low-dose inhibitory and high-dose stimulatory response in J-shaped CRCs (Calabrese 1999), which means that the effect is consid-ered as the response to disruptions in homeostasis that are mediated by agonist concentration gradients with different affinities for stimulatory and inhibitory regulatory path-ways (Calabrese 2001). Li et al. (2014) reported that the response of the GSH-PX activity in E. Andrei during on-going $\mathrm{Al}$ exposure was similar to that of SOD. Similar to our results, Zhou et al. (2016) found no significant corre-lation between the activities of CAT and POD in Eisenia fetida exposure to $\mathrm{Cd}^{2+}$ with different exposure time $(0-30$ days). Zhang et al. (2009) found that $\mathrm{Cd}$ at low concentration $\left(7.01 \mathrm{ng} \mathrm{cm}^{-2}\right)$ induced an increase in the activity of CAT, but high concentration $\left(10.53 \mathrm{ng} \mathrm{cm}^{-2}\right)$ inhibited the enzymes, and this was reflected in an inverted U-shaped curve. Zhou et al. (2016) found that there was no significant difference in CAT activity ob-served among the phenanthrene treatment groups and the control group after 28-day exposures. However, Zhang et al. (2015b) found that the CAT activity in the earth-worm decreased significantly with $\mathrm{pH}$ from 6.5 to 4.0 and there was no statistical difference in CAT activity between $\mathrm{pH} 4.0$ and 3.0. Liu et al. (2011) also reported that under HHCB stress conditions, the activity trend of CAT was in general related to the activity of SOD but HHCB exhibited a different impact on the activity of P O D in E f e t id a f r o $\mathrm{m} \mathrm{th}$ a t o f S O D a n d C AT. Noticeably, in our study, soil acid stress exhibited a dif-ferent impact on the activity of CAT in E. fetida from that of the POD, SOD, and GSH-PX after 28 days of expo-sure. Only CAT showed hormetic response to soil acid stress while CAT activities significantly positively corre-lated with survival, growth rate, cocoon production, and protein contents (TP and MT) of E. fetida. In this respect, these results were not consistent with the results reported by Liu et al. (2011). The reason for this phenomenon may be the mechanisms of CAT and POD (SOD) exposure to soil acid stress that are essentially different and unfolded. TP and MT were always used as biomarkers in response to pesticides (Mosleh et al. 2003) and metals (Dedeke et al. 2016), respectively. Ribeoro et al. (2001) found the reduction of TP contents in earthworms may be as-cribed to a catabolism of proteins in response to worm energy demand as suggested for an isopod in response to pesticides, and this decrease was followed by a reduction in growth. Dedeke et al. (2016) found a signif-icantly positive correlation between MT and metal con-centrations in earthworms. Our results showed that the stimulation of $\mathrm{TP}$ and MT responses to $\mathrm{pH}$ was both in agreement with the occurrence of hormetic phenomenon, which was the same as CAT activities. TP and MT con-tents both have shown low-dose stimulatory and high-dose inhibitory rules (Figs. 2a, b and 3d). The hormetic effect of soil $\mathrm{pH}$ on enzyme activities in earthworm may be interpreted by the biological mechanisms relates to ROS (Razinger et al. 2008), which were triggered by pol-lutants that can do oxidative damage to organisms (Liu et al. 2018). However, it was considered that low dose of ROS (ZEP1 to ZEP 2 ) would induce beneficial effects on organisms.

Accurate modeling of biphasic dose-response is an essential step in establishing effective guidelines for the protection of ecosystem health (Beckon et al. 2008; Ge et al. 2011; Zhang et al. 2009; Zhu et al. 2013). The varieties of antioxidant enzymes and proteins with soil $\mathrm{pH}$ were showing typically inverted U-shaped and J-shaped CRCs, respectively. The magnitude of hormetic effect can be identified by the ratio of AUCH/AUCZEP. According to the AUCH/AUCZEP of CAT (14.83\%), TP (26.67\%), and MT (37.53\%) (as shown in Figs. 2 and 3), the hormetic effect of MT and TP was higher than that of CAT. It also suggests that MT and TP may play an important role in hormetic effect of soil $\mathrm{pH}$ on protein contents. In this study, the ZEP2 of CAT, TP, and MT were 3.60, 3.53 , and 3.88 , respectively. Additionally the zero effects (except the control) of the GSH-PX, SOD, and POD activities were measured at $\mathrm{pH} 3.63,3.56$, and 3.44, respectively. That is, from the perspective of enzyme activities and protein content response to the soil $\mathrm{pH}$, the average critical value was 3.60. The average soil $\mathrm{pH}$ at $\mathrm{E}_{\min }$ of the GSH-PX, SOD, and POD was 4.91 (between 5.2 and 4.0). The average $\mathrm{pH}$ values at the maximal stimulatory effect of CAT, TP, and MT was 4.99 (between 5.2 and 4.0) (Figs. 2 and 3). At day 28, the critical value of worm growth rate was between 5.2 and 4.0 (Fig. 1); the earthworm cocoon number of $\mathrm{pH} 4.0$ treatment was less than half of that of $\mathrm{pH} 5.2$ treatment, but the survival rate was obviously inhibited until $\mathrm{pH}$ 3.0. It implied that there was a consistent response relation between antioxidant enzymes (or proteins) and growth as well as reproduction of earthworms. As for the exception of survival, the possible explanation may be interpreted that, on the one hand, the 
Eisenia fetida, which is recognized as the standard earthworm for toxicological test of the OECD guidelines 222 (OECD 2004), has enhanced its adaptability in the long-term artificial domestication and culture. On the other hand, the culture ma-trix in this experiment embraced soil conditions (adequate organic matter, appropriate moisture and temperature, etc. as described in Materials and methods) required by worms. In this work, we combined the external growth characteristics and intrinsic enzyme characteristics to assess and compare the response of earthworm to soil $\mathrm{pH}$.

Most literatures lack adequate temporal component to dis-cuss the existence of hormetic dose-response with temporal changes (Calabrese 2001; Mattson and Calabrese 2010). In contrast to the traditional tests of acute toxicology, in this work, the hormetic effect of CAT activities and two protein contents was found at the end of the culture period (at 28 days). Calabrese (1999) had found that the phenomenon existed in most of the experimental period. Further investigation wheth-er hormetic effect exists in the whole culture period remains. Although a range ( $\mathrm{pH} 6.3$ to 3.0) of endpoints has proved hormetic responses in present study, it is no clear whether the hormesis exist at a wider range. Considering the diversity of soils, as well as the earthworm species, a single study may not be sufficient to demonstrate the hormetic effects.

\section{Conclusion}

Our study demonstrated firstly that soil $\mathrm{pH}$ value threshold of the significant inhibitory effect on the survival, growth, and reproduction of earthworms were 3.0, 4.0, and 5.2, respective-ly; secondly, the critical value of the antioxidant enzyme ac-tivities and protein contents in Eisenia fetida inhibited by soil acid stress was 3.60 according to biphasic response models. Finally, evidences from this study point out that low dose may lead to an increase of CAT activity and TP and MT contents in Eisenia fetida; however, high acid stress inhibits the activity and contents, which is in agreement with the occurrence of a hormetic phenomenon.

Funding information This research was supported by the Natural Science Foundation of China (U1401234, 41601227 and 41701262) and the National Key Research and Development Program of China (2016YFD0800300, 2016YFD0201301).

\section{Compliance with ethical standards}

Human and animal rights and informed consent We declare that these experiments were conducted in accordance with EC Directive 86/609/ EEC and national and institutional guidelines for the protection of human subjects and animal welfare.

Conflict of interest The authors declare that they have no conflict of interest.
Publisher's note Springer Nature remains neutral with regard to jurisdic-tional claims in published maps and institutional affiliations.

\section{References}

Beckon WN, Parkins C, Maximovich A, Beckon AV (2008) A general approach to modeling biphasic relationships. Environ Sci Technol 42:1308-1314

Bradford MM (1976) Rapid and sensitive method for quantitation of microgram quantities of protein utilizing principle of proteindye binding. Anal Biochem 72(1/2):248-254

Brown TT, Koenig RT, Huggins DR, Harsh JB, Rossi RE (2008) Lime effects on soil acidity, crop yield, and aluminum chemistry in directseeded cropping systems. Soil Sci Soc Am J 72:634-640

Calabrese EJ (2001) Overcompensation stimulation: a mechanism for hormetic effects. Crit Rev Toxicol 31:425-470

Calabrese EJ, Baldwin LA (2003) Toxicology rethinks its central belief. Nature 421:691-692

Calabrese EJ, Blain R (2005) The occurrence of hormetic dose responses in the toxicological literature, the hormesis database: an overview. Toxicol Appl Pharmacol 202:289-301

Calabrese EJ (1999) Evidence that hormesis represents an Bovercompensation ${ }^{\wedge}$ response to a disruption in homeostasis. Ecotoxicol Environ Saf 42:135-137

Chan KY, Mead JA (2003) Soil acidity limits colonisation by Aporrectodea trapezoides, an exotic earthworm. Pedobiologia 47: 225-229

Chen X, Wang XR, Gu XY, Jiang Y, Ji R (2017) Oxidative stress responses and insights into the sensitivity of the earthworms Metaphire guillelmi and Eisenia fetida to soil cadmium. Sci Total Environ 574:300-306

Dedeke GA, Owagboriaye FO, Adebambo AO, Ademolu KO (2016) Earthworm metallothionein production as biomarker of heavy metal pollution in abattoir soil. Appl Soil Ecol 104:42-47

Edwards CA (2004) The importance of earthworms as key representa-tives of the soil fauna. In: Edwards CA (ed) Earthworm ecology. Boca Raton, Florida, pp 3-11

Edwards CA, Bohlen PJ (1996) Biology and ecology of earthworms, third edn. Chapman and Hall, London, pp 142-145

Ge H, Liu S, Zhu X, Liu H, Wang L (2011) Predicting hormetic effects of ionic liquid mixtures on luciferase activity using the concentration addition model. Environ Sci Technol 45:1623-1629

Guo JH, Liu XJ, Zhang Y, Shen JL, Han WX, Zhang WF, Christie P, Goulding KWT, Vitousek PM, Zhang FS (2010) Significant acidification in major Chinese croplands. Science 327:1008-1010

Hackenberger BK, Jarić-Perkušić D, Stepić S (2008) Effect of temephos on cholinesterase activity in the earthworm Eisenia fetida (Oligochaeta, Lumbricidae). Ecotoxicol Environ Saf 71:583-589

Hodson ME, Donner E (2013) Managing adverse soil chemical environ-ments. Blackwell, Chichester, pp 195-237

Homan C, Beier C, Mccay T, Lawrence G (2016) Application of lime $\left(\mathrm{CaCO}_{3}\right)$ to promote forest recovery from severe acidification in-creases potential for earthworm invasion. For Ecol Manag 368:39- 44

Hu SQ, Zhang W, Li J, Lin KF, Ji R (2016) Antioxidant and gene expres-sion responses of Eisenia fetida following repeated exposure to BDE209 and $\mathrm{Pb}$ in a soil-earthworm system. Sci Total Environ 556:163-168

Jia L, Liu ZL, Wei C, Ye Y, Yu S, He XY (2015) Hormesis effects induced by cadmium on growth and phototsynthetic performance in a hyperaccumulator, Lonicera japonica Thunb. J Plant Growth Regul 34:13-21

Kunito T, Isomura I, Sumi H, Park HD, Toda H, Otsuka S, Nagaoka K, Saeki K, Senoo K (2016) Aluminum and acidity suppress microbial 
activity and biomass in acidic forest soils. Soil Biol Biochem 97:23- 30

Li YS, Sun J, Robin P, Cluzeau D, Qiu JP (2014) Responses of earthworm Eisenia andrei exposed to sublethal aluminium levels in an artificial soil substrate. Chem Ecol 7:611-621

Liu S, Zhou QX, Wang YY (2011) Ecotoxicological responses of the earthworm Eisenia fetida exposed to soil contaminated with HHCB. Chemosphere 83:1080-1086

Liu T, Wang XG, Chen D, Li YQ, Wang FL (2018) Growth, reproduction and biochemical toxicity of chlorantraniliprole in soil on earthworms (Eisenia fetida). Ecotoxicol Environ Saf 150:18-25

Mattson MP, Calabrese EJ (2010) Hormesis: a revolution in biology,

toxicology and medicine. Humana. Springer, New York, p 35 Mccallum HM, Wilson JD, Beaumont D, Sheldon R, O'Brien MG, Park

$\mathrm{KJ}$ (2016) A role for liming as a conservation intervention? Earthworm abundance is associated with higher soil $\mathrm{pH}$ and forag-ing activity of a threatened shorebird in upland grasslands. Agric Ecosyst Environ 223:182-189

Moore J, Ouimet R, Bohlen PJ (2013) Effects of liming on survival and reproduction of two potentially invasive earthworm species in a northern forest Podzol. Soil Biol Biochem 64:174-180

Mosleh Y, Paris-Palacios P, Couderchet M, Vernet G (2003) Effects of the herbicide isoproturon on survival, growth rate, and protein content of mature earthworms (Lumbricus terrestris L.) and its fate in the soil. Appl Soil Ecol 23:69-77

Nahmani J, Hodson ME, Black S (2007) Effects of metals on life cycle parameters of the earthworm Eisenia fetida exposed to fieldcontam-inated, metal-polluted soils. Environ Pollut 149:44-58

OECD (2004) Earthworm reproduction tests. Guidelines for testing chemicals. No. 222. OECD, Paris

Qiao X, Xiao WY, Jaffe D, Kota SH, Ying Q, Tang Y (2015) Atmospheric wet deposition of sulfur and nitrogen in Jiuzhaigou National Nature Reserve, Sichuan Province, China. Sci Total Environ 511:28-36

R Development Core Team (2007) R: A language and environment for statistical computing, Vienna, Austria. (ISBN 3-900051-070) http://www.R-project.org/

Razinger J, Dermastia M, Koce JD, Zrimec A (2008) Oxidative stress in duckweed (Lemna minor L.) caused by short-term cadmium expo-sure. Environ Pollut 153:687-694

Ribeoro S, Sousa JP, Nogueira AJA, Soares AMVM (2001) Effect of endosulfan and parathion on energy reserves and physiological pa-rameters of the terrestrial isopod Porcellio dilatatus. Ecotoxicol Environ Saf 49:131-138

Rusek J, Marshall VG (2000) Impacts of airborne pollutants on soil fauna. Annu Rev Ecol Syst 31:395-423

Sanchez-Hernandez JC, Narvaez C, Sabat P, Martinez Mocillo S (2014) Integrated biomarker analysis of chlorpyrifos metabolism and tox-icity in the earthworm Aporrectodea caliginosa. Sci Total Environ 490:445-455

Shi Z, Tang Z, Wang C (2017) A brief review and evaluation of earth-worm biomarkers in soil pollution assessment. Environ Sci Pollut Res 24:13284-13294

Spurgeon DJ, Hopkin SP (1996) Effects of variations of the organic matter content and $\mathrm{pH}$ of soils on the availability and toxicity of zinc to the earthworm Eisenia fetida. Pedobiologia 40:80-96
Tejada M, Gómez I, Hernández T, García C (2010) Response of Eisenia fetida to the application of different organic wastes in an aluminiumcontaminated soil. Ecotoxicol Environ Saf 73:1944-1949

Tian DS, Niu SL (2015) A global analysis of soil acidification caused by nitrogen addition. Environ Res Lett 10 . https://doi.org/10.1088/ 1748-9326/10/2/024019

Velki M, Hackenberger BK (2013) Biomarker responses in earthworm Eisenia andrei exposed to pirimiphos-methyl and deltamethrin using different toxicity tests. Chemosphere 90:1216-1226

Wang J, Wang JX, Xu C, Liu R, Chen YD (2016) Molecular mechanism of catalase activity change under sodium dodecyl sulfate-induced oxidative stress in the mouse primary hepatocytes. J Hazard Mater 307:173-183

Wei H, Liu W, Zhang JE, Zhong Q (2017) Effects of simulated acid rain on soil fauna community composition and their ecological niches. Environ Pollut 220:460-468

Wu SJ, Wu EM, Qiu LQ, Zhong WH, Chen JM (2011) Effects of phen-anthrene on the mortality, growth and anti-oxidant system of earth-worms (Eisenia fetida) under laboratory conditions. Chemosphere 83:429-434

Zeng MF, Vries WD, Bonten LTC, Zhu QC, Hao TX, Liu XJ, Xu MG, Shi XJ, Zhang FS, Shen JB (2017) Model-based analysis of the long-term effects of fertilization management on cropland soil acid-ification. Environ Sci Technol 51:3843-385

Zhang Y, Shen GQ, Yu YS, Zhu HL (2009) The hormetic effect of cad-mium on the activity of antioxidant enzymes in the earthworm Eisenia fetida. Environ Pollut 157:3064-3068

Zhang JE, Yu JY, Ouyang Y, Xu HQ (2013) Responses of earthworm to aluminum toxicity in latosol. Environ Sci Pollut Res 20:1135-1141

Zhang JQ, Shen M, Zhu CC, Yu FX, Liu ZQ, Ally N, Sun SC, Li K, Liu HL (2014) 3-Nitropropionic acid induces ovarian oxidative stress and impairs follicle in mouse. PLoS One 9:e86589

Zhang JE, Yu JY, Ouyang Y (2015a) Activity of earthworm in latosol under simulated acid rain stress. Bull Environ Contam Toxicol 94: 108-111

Zhang Q, Zhang G, Yin P, Lv Y, Yuan S, Chen J, Wei B, Wang C (2015b) Toxicological effects of soil contaminated with spirotetramat to the earthworm Eisenia fetida. Chemosphere 139:138-145

Zhang XM, Liu W, Zhang GM, Jiang L, Han XG (2015c) Mechanisms of soil acidification reducing bacterial diversity. Soil Biol Biochem 81: 275-281

Zhao Y, Duan L, Xing J, Larssen T, Nielsen PC, Hao JM (2009) Soil acidification in China: is controlling $\mathrm{SO}_{2}$ emissions enough? Environ Sci Technol 43:8021-8026

Zhao FJ, Ma YB, Zhu YG, Tang Z, McGrath SP (2015) Soil contamina-tion in China: current status and mitigation strategies. Environ Sci Technol 49:750-759

Zhou DX, Ning YC, Wang B, Wang GD, Su Y, Li L, Wang Y (2016) Study on the influential factors of $\mathrm{Cd}^{2+}$ on the earthworm Eisenia fetida in oxidative stress based on factor analysis approach. Chemosphere 157:181-189

Zhu XW, Liu SS, Qin LT, Chen F, Liu HL (2013) Modeling nonmonotonic dose-response relationships: model evaluation and hormetic quantities exploration. Ecotoxicol Environ Saf 89:130136 